\title{
The Development of Regional Management by Smoothing of Spatial Polarization
}

\author{
Zinovyeva A. A. ${ }^{1}$ \\ ${ }^{1}$ Kazan Federal University, Institute of Management, Economics and Finance, Kazan, 420008, Russia \\ Correspondence: Zinovyeva A. A., Kazan Federal University, Institute of Management, Economics and Finance, \\ Kazan, 420008, Russia.
}

Received: March 10, 2015 Accepted: March 31, 2015 Online Published: April 30, 2015

doi:10.5539/ass.v11n11p253 URL: http://dx.doi.org/10.5539/ass.v11n11p253

\begin{abstract}
The article briefly highlights main theoretical approaches to understanding the uneven of spatial development. The analysis of existing methods of evaluating the effectiveness of management by smoothing of spatial polarization in the region was made. The methods of evaluating the effectiveness of state and municipal administrating systems were described. The system of indicators for assessing management effectiveness of economic territory polarization in the region was studied.
\end{abstract}

Keywords: unevenness of spatial development, the system of indicators for assessing management effectiveness of the smoothing spatial polarization in the region

\section{Introduction}

The maintenance of Russian economy effective transit to the innovation-based development should be based on forming a platform for sustainable development (Gabdrakhmanov \& Rubtzov, 2014), establishment of which involves the implementation of the balance principle in management, realization of which in a disproportionate Russian economy primarily must be fulfilled on a regional level. Existent centralization of power and responsibility for developing the system of economic territory polarization management on federal level preclude from realizing effective business mechanisms for management of economic territory sustainable development, which, in particular, provides insufficient efficiency of infrastructure projects implementation, directed at smoothing of territory polarization (Gabdrakhmanov, Rubtzov, Mustafin, \& Pratchenko, 2014). Latter, in its turn, determine enhancement of interregional and intraregional differentiation tendencies, that creates the conditions for concentration of national economic and social system's development recourses in metroplexes, that discourage rational utilization of economic territory in Russian Federation and prevents the establishment of transition mechanism to the innovation-based development. The solution to this problem lies in the field of rational distribution of powers and responsibilities for management of spatial polarization smoothing on local, regional and federal levels, provided that the concentration of noted powers must be located at the meso-level, which will allow taking into account individual characteristics of territories and create conditions for its effective sustainable development.

\section{Method}

Spatial development of Russian regions could be characterized by a strong polarization and by enhancement of dissolution tendency in socioeconomic indicators (Gabdrakhmanov \& Rozhko, 2014). The concept of long-term socioeconomic development for the period until 2020 provides balanced spatial development, based on the establishment of regional growth centers in regions that assimilate new primary recourses, and also in traditional regions that concentrate innovational, industrial and agricultural potential of Russia (Bagautdinova, Hadiullina, Sarkin, \& Pratchenko, 2014).

In regional science from the second half of the twentieth century settled consensus of opinion within the meaning of spatial development had been developed - it could not be proportional. This is explained by two main conceptions, which withstand the test of time.

Firstly it is a center-peripheral theory (model) of spatial development, formulated by J. Friedman (Friedmann, 1966): centers of different levels always concentrate resources (human, financial, nature) from its periphery, it is concentration of resources that creates opportunities for innovational changes of the centers themselves, and then 
these innovations broadcast to the periphery with a lag of time, depending on the size of barriers in the way of innovations. Between centers and peripheries there is mobile zone of semi-periphery, which is more active and could intercept the functions of center in case of sudden change in the conditions of development. This theory works at all levels - from world Cities and large agglomerations to regional and local centers (Gabdrakhmanov \& Rubtsov, 2014; Gabdrakhmanov, Rubtzov, Mustafin, \& Pratchenko, 2014).

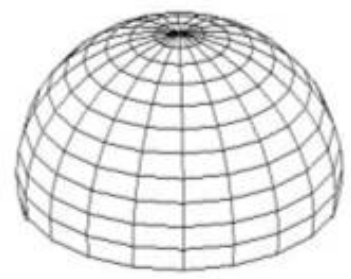

a)

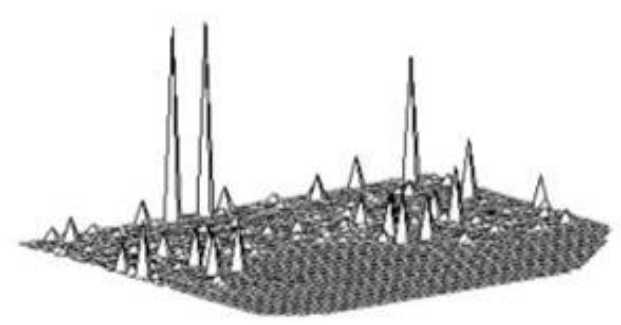

b)

Figure 1. Configuration of economic space of Russia: a) ideal option; в) real situation

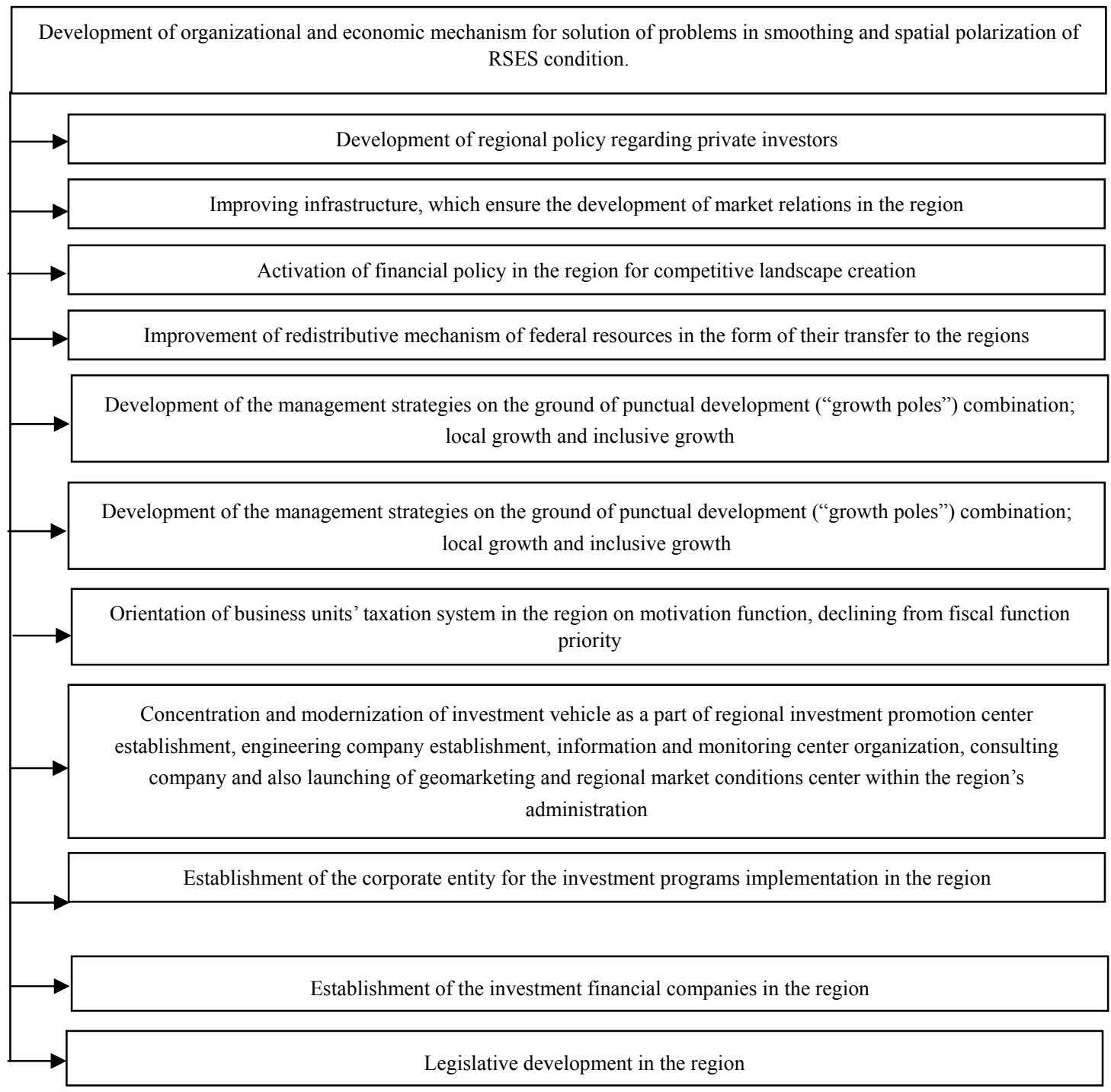

Figure 2. The complex of the recommended strategic directions of a sustainable development of the territory economy 
Secondly these are studies of the processes of spatial concentration of the economy, including in the framework of the "new economic geography" (Isard, 1960). Fundamental reason of economical inequality is long studied in regional science process of concentration of economic activity in such places, which have comparative advantages that allows them to reduce business expenses. Among such advantages P. Krugman (Krugman, 1991) identifies factors of "first nature" (wealth of natural resources, advantageous geographical location), which little depend on human, and factors of "second nature" (agglomerative effect, human capital assets, institutional environment) to the fullest extent related to the activities of the state and society. Factors of "first nature" dominated on the stage of industrial development, with the passage to the postindustrial economy function of factors of "second nature" rises sharply. Namely they play a key role in modernization, while relying of region's development on resource advantages slow it down.

According to the researches, for all countries, regardless of their level of development, are indicative the tendencies of territorial concentration of the economy in regions with competitive advantages. Economic inequality of the country forms under the influence of objective factors, for that reason it is impossible to level it (Wallerstein, 1974, 1980, 1989). The only difference is that in affluent countries already oriented on the factors of "second nature" expansion rate of regional economical inequalities are low because the peak of inequality growth fell on the beginning of XX century. In countries with catching-up development economical inequality of regions advance faster, thereby repeating Western European trend from a century ago (Myrdal, 1957). Russia is a country with catching-up development therefore the growth of economical inequality of regions is unavoidable, however over the long term, more than likely not far, its rate should slow (Gabdrakhmanov \& Rubtsov, 2014).

Spatial inequality is inevitable, however advantages, and especially of "first nature" is not eternal. In early industrial era overarching factors of development were availability of mineral resources and geographical location, in industrial era - capital and institutes, and in postindustrial - human recourses and technologies (Bell, 1976; Gabdrakhmanov, Rubtzov, Mustafin, \& Antonova, 2014).

\section{Result}

First of all it seems appropriate to undertake a study of existing methods of evaluating the effectiveness of management by smoothing of spatial polarization in the region. Assertion that national administration of economy should be effective is not subject to doubt. Furthermore, quite frequently we can hear calls to improve quality and effectiveness of state economic entities and state property management. At times we could read and hear that management in general and state administration in particular is capable to be not only effective and useful, but even optimal and perfect. Whereupon original concepts itself: "management quality", "competence of management", "optimality of management", did not receive a clear explanation or description neither in theory of economic management nor in economic science. Some authors emanate from the concept that the meaning of these terms is axiomatic, although it is difficult to agree with such conclusion. More often than not there are attempts to interpret the concept "managerial efficiency" by analogy with similar in meaning concept "operating efficiency" or "resource efficiency". Latter concept partially identifies with related term "return of spent resources". Whereas the basis of statement about efficiency and its definition by calculation sets up a ratio: "expenses - result" (Fukuchi, 2000). Summing up what has been said; in the broad sense of the word "efficiency" should be understood as balance between accomplished results of economic activity and total expenditures of resources gained to obtain these results.

It will be observed that consistent methodology of performance evaluation of systems of central and local government, including quality of life management, has not been developed yet. Deserve attention following approaches of performance evaluation of governing boards that most frequently apply at the moment: general effectiveness, economic effectiveness, effectiveness, efficiency (Bagautdinova, Kharisova, \& Kharisova, 2014). Consider these approaches in more detail.

1. General effectiveness. Measures of performance of central and local government could be sized on the degree of achievement of their goals. As previously stated, the main objective of system of central and local government is to influence the local system of sub national entity to transfer it into the state that ensures conditions for the production and reproduction of immediate life and also conditions for decent life and easy development of people.

As indicators of achievement of main objective of central and local government we consider three coefficients: index of population survival level (Кув); index of living standards of the population (Куж); index of human rights violations level (Кунпч). These coefficients express essentially the ratio of goals and outcomes. Summarized index of overall relative effectiveness of central and local government system is represented as product of these three coefficients: 


$$
\kappa_{\mathrm{cy}}=\text { Кув* Куж* Кунпч }
$$

where, $K_{\mathrm{cy}}$ - generalized coefficient of objective fulfillment of central and local government system.

2. Economic effectiveness of system of public administration. The factors of economics efficiency of central and local government system include following factors:

a) cost value for sustenance of supervision system administration depending on population size;

b) the size of budget fraction of jurisdiction on one employee of supervision system administration or on Ruble of costs value for sustenance of this administration.

3. Rating of effectiveness. Rating of effectiveness of central and local government systems is advisable to carry out on the ground of assessment of their organizational and technical level. Such assessment is complex and includes as indicators following coefficients in a formula:

$$
\ni=\Sigma \mathrm{K}_{\mathrm{i}} / \mathrm{n}
$$

where, $Э_{\text {огу }}$ - effectiveness of organizational and technical level of central and local government system;

$\mathrm{n}-$ number of coefficients, in that case $\mathrm{n}=11$;

$\mathrm{K}_{1}=\mathrm{C}_{1} / \mathrm{C}-$ level of specialization of employee labor;

$K_{2}=\Phi_{1} / \Phi-$ level of management engineering;

$\mathrm{K}_{3}=\mathrm{P}_{1} / \mathrm{P}-$ quality control level of realization of managerial decision;

$\mathrm{K}_{4}=\mathrm{C} \Pi / \mathrm{C}-$ level of quality planning of employees activity;

$\mathrm{K}_{5}=\mathrm{CO} / \mathrm{C}-$ percentage of employees, performance quality of whom is constantly measuring;

$\mathrm{K}_{6}=1-\mathrm{C}_{2} / \mathrm{C}-$ level of employee loyalty;

$\mathrm{K}_{7}=1-\mathrm{C}_{3} / \mathrm{C}-$ level of employee discipline;

$\mathrm{K}_{8}=1-\mathrm{C}_{4} / \mathrm{C}-$ quality level of employee working place;

$\mathrm{K}_{9}=\mathrm{C}_{5} / \mathrm{C}-$ level of informational support;

$\mathrm{K}_{10}=\mathrm{C}_{6} / \mathrm{C}-$ quality level of employees professional qualifications;

$K_{11}=1-\mathrm{O}_{1} / \mathrm{O}$ - level of work with citizens compellations in the agencies of central and local government.

4. Quantitative assessment of efficiency. To the quantitative methods of efficiency assessment of central and local government systems can be attributed:

a) the amount of central and local government system administration compared with population size of corresponded jurisdiction;

b) correlation between the amount of jurisdiction GDP on one Ruble of costs value for sustenance of this administration or one employee.

Alongside with the existing methods of evaluating the effectiveness of public administration by quality of life, from our point of view, should be used integral criterion of quality of life in the region.

As evidenced by our researches, as a summary index that characterize the efficiency of social and economic programs realization, it is advisable to use quality of life index, computed using the following formula:

$$
\mathrm{I}_{\mathrm{in}}=1 / \mathrm{n} \Sigma \mathrm{I}_{\mathrm{i}}
$$

where, $\mathrm{n}$ - number of indexed figures;

I - the benchmark index.

Among benchmark indexes we used following: duration of life, attained level of education, corrected per capita GDP (I II III in \$US) (World Development Report, 2009). If it is necessary could be used other indexes that determine more specific aspects of the research, for example indexes of poverty, unemployment, housing per capita and other.

In the meantime it should be noted that represented approach is also inaccurate, because in the current context there is almost impossible to find benchmark data, essential for this calculation. As a consequence it seems necessary to buildup specific approach of assessing the management effectiveness of spatial polarization smoothing in the region with due account for the impact of key sub-potentials. 


\section{Conclusion}

Assessing of management effectiveness of spatial polarization smoothing in the region should be carried out in the form of integrated index that take into account correlation of expenses and control effects in view of key sub-potentials that provide positive progressive dynamics of index numbers, characterizing the level of economic territory polarization. At the same time consideration must be given to the significance of each innovational, infrastructure and social sub-potential, which is estimated according to the Pearson paired correlation coefficients comparison. These coefficients are calculated on a comparison basis of level of development of noted sub-potentials and resulting indexes of regional development that illustrate present level of economic territory polarization ( $\mathrm{Li}$, Wang, Zhao, Jia, \& Su, 2014). Constructed in such a way system of indexes of management effectiveness of economic territory polarization in the region presented in Table 1.

Table 1. The system of indicators for assessment management effectiveness of the polarization of the economic space of the region

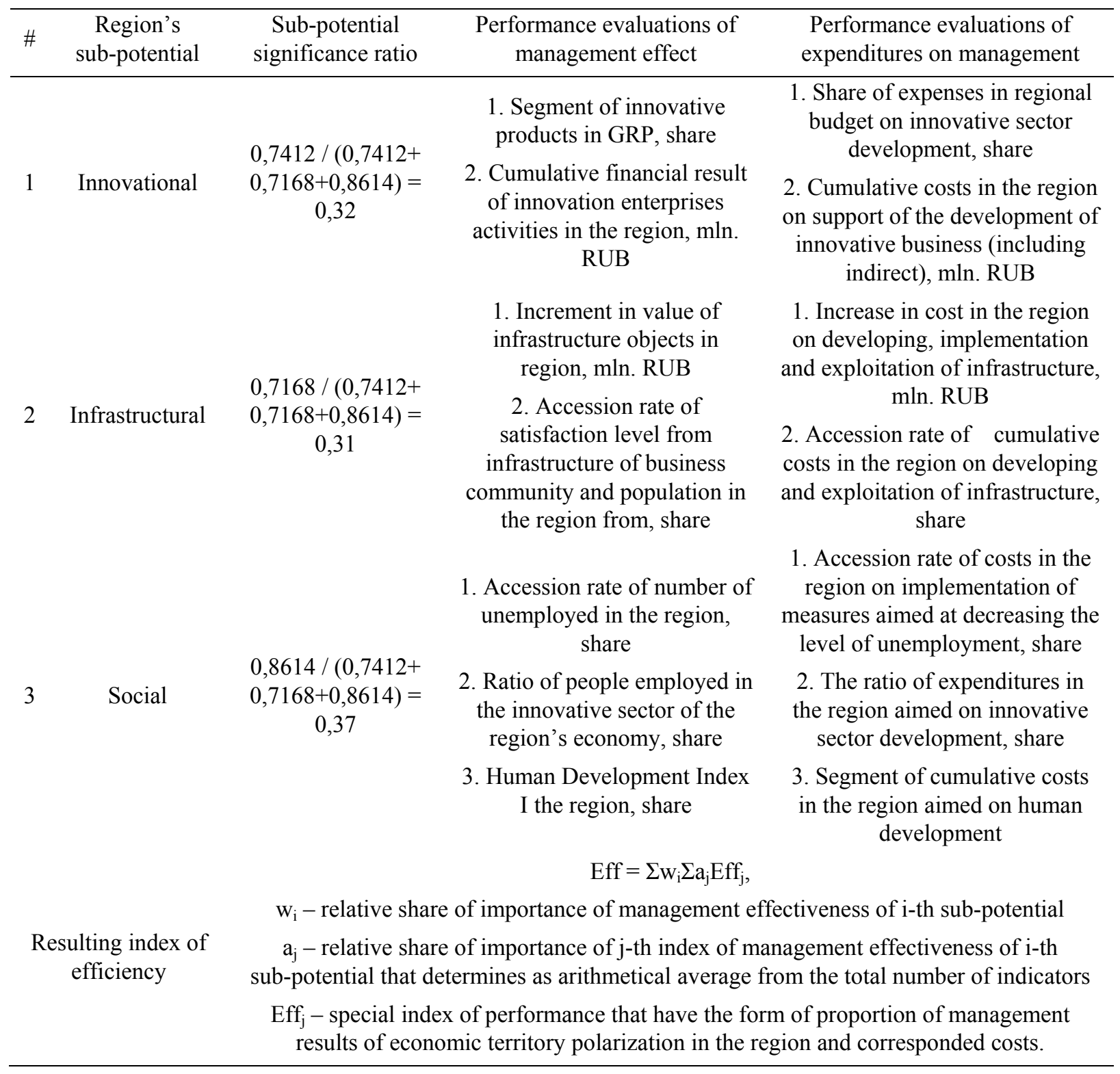

The analysis of received resulting index of assessing management effectiveness of economic territory polarization in the region in dynamics will allow to define the level of management quality of such process and to formulate main directions of its development. 
Summing up what has been said, main methodological instrument of management of spatial polarization smoothing on the ground of implementation of infrastructure projects had been determined.

\section{References}

Bagautdinova, N. G., Hadiullina, G. N., Sarkin, A. V., \& Pratchenko, O. V. (2014). Typology of the regions with the account of level of influence of infrastructure facilities on the structure of economic areas. Asian Social Science, 10, 57-61. http://dx.doi.org/10.5539/ass.v10n20p57

Bagautdinova, N. G., Kharisova, G. M., \& Kharisova, R. R. (2014). Influence of infrastuctural complex on the wealth and lines of development of regional economic space. Asian Social Science, 10(24), 198-202.

Bell, D. (1976). The Coming of Post-Industrial Society. A Venture in Social Forecasting. N.Y., Basic Books.

Friedmann, J. (1966). Regional Development Policy (p. 279). Cambridge, MA, MIT Press.

Fukuchi, T. (2000). Long-run development of a multi-regional economy (Vol. 79). Papers in Regional Science.

Gabdrakhmanov, N. K., \& Rozhko, M. V. (2014). Positioning of Volga Federal District Regions by Demographic Situation Index. World Applied Sciences Journal, 30(6), 792-795.

Gabdrakhmanov, N. K., \& Rubtsov, V. A. (2014a). The Objects of Social Infrastructure in the Social Image of the Region Shaping. Procedia - Social and Behavioral Sciences, 140, 419-421. http://dx.doi.org/10.1016/j.sbspro.2014.04.446

Gabdrakhmanov, N. K., \& Rubtsov, V. A. (2014b). Tourist and Recreational Positioning of Tatarstan Republic: Cluster Analysis. World Applied Sciences Journal, 30(Management, Economics, Technology \& Tourism), 202-205.

Gabdrakhmanov, N. K., \& Rubtzov, V. A. (2014). Geodemographic Polarization Processes: Municipal Level (The Case of the Kukmorsky Municipal District of the Republic of Tatarstan). World Applied Sciences Journal, 30(10), 1317-1320.

Gabdrakhmanov, N. K., Rubtzov, V. A., Mustafin, M. R., \& Antonova, N. V. (2014). Analysis of Life Expectancy Rate at Birth in the Republic of Tatarstan. Mediterranean Journal of Social Sciences, 5(24), 272-278. http://dx.doi.org/10.5901/mjss.2014.v5n24p272

Gabdrakhmanov, N. K., Rubtzov, V. A., Mustafin, M. R., \& Pratchenko, O. V. (2014). Model of Sustainable Development of the Region. Mediterranean Journal of Social Sciences, 5(24) 393-398. http://dx.doi.org/10.5901/mjss.2014.v5n24p393

Gabdrakhmanov, N. K., Rubtzov, V. A., Mustafin, M. R., \& Pratchenko, O. V. (2014). Geodemographic Potential of the Republic of Tatarstan: Analysis, Evaluation, Territorial Differences. Mediterranean Journal of Social Sciences, 5(24), 278-285. http://dx.doi.org/10.5901/mjss.2014.v5n24p278

Isard, W. (1960). Methods of Regional Analysis: An Introduction to Regional Science. Hardcover.

Krugman, P. R. (1991). Geography and Trade. MIT Press, Cambridge, MA.

Li, P., Wang, W., Zhao, R.-C., Jia, H.-T., \& Su, J.-Q. (2014). Polarization smoothing design for improving the whole spatial frequency at focal spot. Acta Physica Sinica, 63(21), 8.

Myrdal, G. (1957). Economic Theory and Underdeveloped Regions. London, Duckworth.

Wallerstein, I. (1974, 1980, 1989). The Modern World-System (Vol. 1: Capitalist Agriculture and the Origins of the European Word-Economy in the Sixteenth Century; Vol. 2: Mercantilism and the Consolidation of the European Word-Economy, 1600-1750; Vol. 3: The Second Era of Great Expansion of the Capitalist Word-Economy, 1730-1840). N.Y., Academic Press.

World Development Report. (2009). World Bank (p. 383). Reshaping Economic Geography, 2008-11.

\section{Copyrights}

Copyright for this article is retained by the author(s), with first publication rights granted to the journal.

This is an open-access article distributed under the terms and conditions of the Creative Commons Attribution license (http://creativecommons.org/licenses/by/3.0/). 